CARPATHIAN JOURNAL OF FOOD SCIENCE AND TECHNOLOGY

journal homepage: http://chimie-biologie.ubm.ro/carpathian_journal/index.html

\title{
ANTHROPOMETRIC MEASUREMENTS AND INFLAMMATORY BIOMARKERS IN OBESE ADOLESCENTS
}

\author{
Nur Aisiyah Widjaja ${ }^{1 *}$, Roedi Irawan ${ }^{1}$, Meta Herdiana Hanindita ${ }^{1}$, Rendi Aji Prihaningtyas ${ }^{1}$, \\ Boerhan Hidajat ${ }^{1}$ \\ ${ }^{I}$ Department of Child Health, Dr. Soetomo Hospital, Faculty of Medicine, Universitas Airlangga, \\ Surabaya, Indonesia \\ *nuril08@yahoo.com \\ https://doi.org/10.34302/crpjfst/2019.11.5.13 \\ Article history: \\ Received: \\ 9 March 2019 \\ Accepted: \\ 20 September 2019 \\ Keywords: \\ Obesity; \\ hsCRP; \\ $T N F-\alpha$; \\ Waist circumference; \\ Waist to hip ratio.

\begin{abstract}
Obesity is related to chronic inflammation. Various anthropometric measurements have been shown to be associated with complications of obesity. Identification of the most accurate anthropometric measurement correlated with inflammation could lead to early interventions. The aim of this study was to determine the correlation between anthropometric measurements and inflammatory biomarkers in obese adolescents.

A cross-sectional study was performed on obese adolescents at the Pediatric Nutrition Clinic of Dr Soetomo Hospital, Surabaya. The inflammatory markers High Sensitivity C-Reactive Protein (hsCRP) and Tumor Necrosis Factor Alpha (TNF- $\alpha$ ) were measured using ELISA. Anthropometric measurements including BMI $\left(\mathrm{kg} / \mathrm{m}^{2}\right)$, waist circumference $(\mathrm{cm})$, and waist to hip ratio (WHR) were performed. Statistical analysis was performed using a correlation test with significance set at $\mathrm{p}<0.05$.

In total, 59 adolescents aged 13-16 years were included. The mean BMI was $31.99(26.6-41.13) \mathrm{kg} / \mathrm{m}^{2}$ and the mean waist circumference was 100.18 $(75-122) \mathrm{cm}$. There was no correlation between TNF- $\alpha$ and BMI $(\mathrm{r}=-0.094$; $\mathrm{p}=0.479)$, waist circumference $(\mathrm{r}=-0.041 ; \mathrm{p}=0.757)$, or WHR $(\mathrm{r}=0.041$; $\mathrm{p}=0.759)$. There was also no correlation between hsCRP and BMI $(\mathrm{r}=0.184$; $\mathrm{p}=0.162)$ or WHR $(r=0.146 ; \mathrm{p}=0.274)$. However, hsCRP had a weak positive correlation with waist circumference $(\mathrm{r}=0.315 ; \mathrm{p}=0.015)$. Waist circumference could serve as an indicator of a systemic inflammatory state in adolescents with obesity.
\end{abstract} \\ ABSTRACT
}

\section{Introduction}

Obesity is a global issue that is related to morbidity and mortality. Obesity causes chronic inflammation of the adipose tissue which is involved in the production of adipocytokines, such as IL-1, IL-6, IL-8, TNF- $\alpha$, resistin, and leptin (Castro et al., 2017). Adipocytokine production by adipose tissue results in a proinflammatory condition and oxidative stress (Ellulu et al., 2017). This condition impacts cell function, thus causing diseases such as metabolic syndrome (Castro et al., 2017). Metabolic syndrome is a cluster of cardio metabolic risk factors which includes obesity (Roberts et al., 2013).

Anthropometric measurements of waist circumference and the WHO method of defining obesity in adults have been studied. A waist circumference of $76.8 \mathrm{~cm}$ (men) and $71.7 \mathrm{~cm}$ (women) is associated with obesity and a waist to hip ratio (WHR) of 0.86 (men) and 0.77 (women) is the cut-off used to define obesity (Hastuti et al., 2017). A study in adults showed that WHR is a poor predictor of obesity, especially in women, compared to other 
anthropometric parameters (Sinaga et al., 2018). On the other hand, another study in adults revealed that waist circumference has an impact on inflammatory conditions and a further study mentioned that waist circumference is a weak indicator of elevated hsCRP and decreased adiponectin (Schlecht et al., 2016). A study in children stated that a WHR of greater than or equal to 0.51 is associated with a higher risk of inflammation (Mendes et al., 2017). However, the results of the above-mentioned studies remain controversial. The aim of this study was to determine the association between anthropometric measurements (BMI, waist circumference, and WHR) with inflammatory biomarkers in obese adolescents.

\section{Materials and methods}

This was a cross-sectional study in adolescents aged 13-16 years with obesity. The exclusion criteria for this study were corticosteroid therapy in the 6 months immediately prior to the study, antibiotic use, hormonal therapy, alcohol consumption or smoking, the presence of an infection, immunity or endocrine disorder.

\subsection{Anthropometric measurements}

Anthropometric measurements are a series of measurements performed by trained medical practitioners which include weight, height, waist circumference, and thigh circumference. Weight was measured with the individuals not wearing shoes, and wearing clothes with a weight of less than $0.1 \mathrm{~kg}$, without any other accessories, using a digital scale (Seca, Germany). Height was measured in an upright position, without the presence of clothes or head covers, and using a Seca stadiometer. Body mass index (BMI) was defined as weight (in kilograms) divided by the square of height (in metes). Waist and thigh circumference were measured using metlin. Waist circumference was measured from the midpoint between the iliac crest and the lowest rib.

\subsection{TNF alpha test}

TNF alpha is a pro-inflammatory cytokine synthesised in macrophages in adipose tissue
(Lee et al., 2013). The TNF- $\alpha$ test was performed using the ELISA method from Bioassay Technology Laboratory (China), and measured in $\mathrm{ng} / \mathrm{L}$. The concentration was determined using a standardised curve established by the manufacturer.

\subsection{CRP test}

CRP is a systemic inflammation marker and a nonspecific acute phase reactant produced in the liver. CRP is commonly used to detect inflammation and infections which cause injury to the liver. The hsCRP test was performed using an ELISA method from Diagnostic Biochem Canada Inc. (Canada), and measured in $\mathrm{ng} / \mathrm{mL}$. A study in adults showed that an increased CRP level of $>10 \mathrm{mg} / \mathrm{L}$ in obese women is more likely to be caused by chronic inflammation than acute inflammation; thus, a CRP level of $>10 \mathrm{mg} / \mathrm{L}$ could distinguish between acute and chronic inflammation in obese women (Ishii et al., 2012).

\subsection{Statistics method}

Average values, minimum values, and maximum values were analysed using quantitative parameters. The correlation between TNF- $\alpha$, hsCRP, BMI, waist circumference, and WHR was analysed using bivariate analysis with a significant $\mathrm{p}$ value of $<0.05$. If the data showed normal distribution, analysis was conducted using Pearson correlation; otherwise, Spearman's rho was used. Analysis was performed using the SPSS software package.

\section{Results and discussions}

In this study, there were 59 adolescents with obesity, consisting of $32 \quad(54.2 \%)$ male adolescents and 27 (45.8\%) females, as shown in Table 1.

There was no correlation between TNF- $\alpha$ and BMI $(\mathrm{r}=-0.094 ; \mathrm{p}=0.479)$, waist circumference $(\mathrm{r}=-0.041 ; \mathrm{p}=0.757), \quad$ or WHR $\quad(\mathrm{r}=0.041$; $\mathrm{p}=0.759)$. hsCRP did not show any correlation with BMI $(r=0.184 ; \mathrm{p}=0.162)$ or WHR $(\mathrm{r}=0.146$; $\mathrm{p}=0.274$ ). However, hsCRP showed a low 
positive correlation with waist circumference $(\mathrm{r}=0.315 ; \mathrm{p}=0.015)$, as shown in Table 2

Table 1. Characteristics of study subjects

\begin{tabular}{|l|c|}
\hline Variable & Number (percentage) \\
\hline Sex & $32(54.2)$ \\
Male & $27(45.8)$ \\
Female & $2(3.4)$ \\
\hline Maternal Education & $4(6.8)$ \\
Uneducated & $5(8.5)$ \\
Elementary School & $25(44.1)$ \\
Middle School & $5(8.5)$ \\
High School & $17(28.8)$ \\
Diploma & $1(1.7)$ \\
Bachelor & $5(8.5)$ \\
\hline Paternal Education & $3(5.1)$ \\
Uneducated & $31(52.5)$ \\
Elementary School & $4(6.8)$ \\
Middle School & $15(25.4)$ \\
High School & \\
Diploma & $36(61)$ \\
Bachelor & $23(39)$ \\
\hline Maternal Occupation & \\
Employed & $80.77(53.5-112)$ \\
Homemaker & $158.76(140.8-175.5)$ \\
\hline Mean (Average) & $31.99(26.6-41.13)$ \\
\hline Weight (kg) & $100.18(75-122)$ \\
\hline Height (cm) & $0.9477(0.79-1.04)$ \\
\hline Body Mass Index $\left(\mathrm{kg} / \mathrm{m}^{2}\right)$ & $(20.63-337.11)$ \\
\hline Waist Circumference $(\mathrm{cm})$ & \\
\hline Waist to hip ratio & \\
\hline TNF- $\alpha$ (ng/l) & $285.79-2941.37)$ \\
\hline hsCRP (ng/ml) & \\
\hline
\end{tabular}

Table 2. Correlation among variables

\begin{tabular}{|c|c|c|c|}
\hline Variable & BMI & Waist circumference & WHR \\
\hline TNF- $\alpha$ & -0.094 & -0.041 & 0.041 \\
\hline $\mathrm{r}$ & 0.479 & 0.757 & 0.759 \\
\hline $\mathrm{p}$ & 0.184 & 0.315 & 0.146 \\
\hline hsCRP & 0.162 & 0.015 & 0.274 \\
\hline $\mathrm{R}$ &
\end{tabular}


Obesity is associated with subclinical inflammation because there is an imbalance in inflammation mediators (Todendi et al., 2016). Subclinical inflammation takes place when BMI rises (del Mar Bibiloni et al., 2013). Adipose tissue produces adipokines (such as resistin, adiponectin, leptin, and visfatin), proinflammatory cytokines, and anti-inflammatory markers (Lee et al., 2013).

Inflammation is associated with a risk of cardiovascular diseases in children (Caminiti et al., 2016). Levels of the inflammatory marker hsCRP rise when there is an increase in body fat levels (Singer et al., 2014). Body fat and adipose tissue reserves are associated with cardio metabolic diseases in children and adults (Staiano and Katzmarzyk, 2012). As fat percentage increases, there is a greater risk of cardiovascular disease in children, especially with a body fat percentage of greater than $20 \%$ in both sexes (Going et al., 2011).

Anthropometric measurements are appropriate for detecting overweight/obesity in children; these include BMI, waist circumference, and arm circumference (Shafiee et al., 2018). An increase in abdominal fat level is associated with an increase in inflammatory markers (Toemen et al., 2015). Inflammatory conditions in obesity are marked by an increase in TNF- $\alpha$ and hsCRP (Ayoub et al., 2015).

A study in children with an average age of $10.03 \pm 0.74$ years showed that waist circumference is positively correlated with TNF- $\alpha$ levels (Guedes et al., 2016). This is in accordance with another study in adults which mentioned that waist circumference is positively correlated with TNF- $\alpha$ levels (Marques-Vidal et al., 2012). In this study there was no correlation between anthropometric measurements with TNF- $\alpha$ level (Table 2.)

HsCRP could be utilised as an early inflammatory marker in obesity. The prevalence of hsCRP levels higher than $3 \mathrm{mg} / \mathrm{L}$ in obese children is 4.15 , falling to 1.91 in overweight children (Todendi et al., 2016). In this study, there was a positive correlation between hsCRP and waist circumference (Figure 1.). Waist circumference has a strong correlation with inflammation (Arbel et al., 2012). Another study showed that CRP is not correlated with waist circumference (Bea et al., 2018). A study in obese pre-adolescent girls showed that waist circumference could be a better indicator of cardio metabolic risk than BMI (HetheringtonRauth et al., 2017). Waist circumference is a predictor of insulin resistance in obese boys and girls (Reyes et al., 2011). A study in non-obese girls also revealed that waist circumference is an independent predictor of insulin resistance compared to BMI (Wolfgram et al., 2015); this is due to visceral fat in the abdomen being proinflammatory. Visceral fat in the abdomen is exposed to macrophage infiltration, which causes cell dysfunction and metabolic syndrome (Weber et al., 2014).

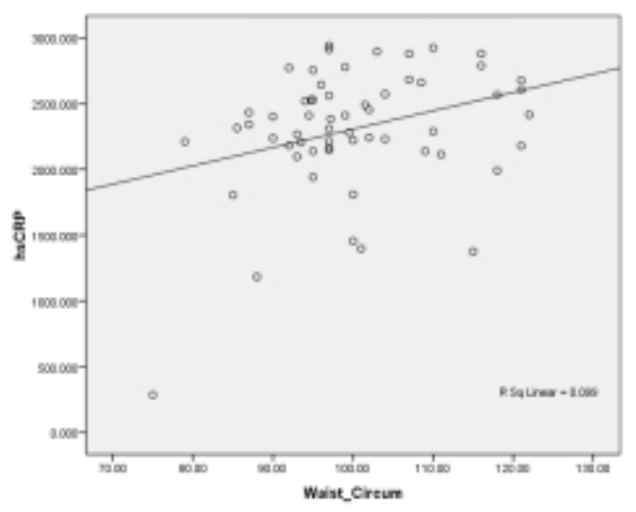

Figure 1. Correlation between hsCRP and waist circumference.

In this study, there were no correlation between hsCRP with BMI and WHR (Figure 2. and 3.). BMI has a strong correlation with inflammation (Arbel et al., 2012), but another study showed that BMI is not correlated with inflammation (Bea et al., 2018).

The combination of BMI and waist circumference increase inflammation, showed in increased hsCRP levels (Todendi et al., 2016). Another study showed that BMI with WHR are more accurate at predicting inflammation in obese children (Samouda et al., 2015). 


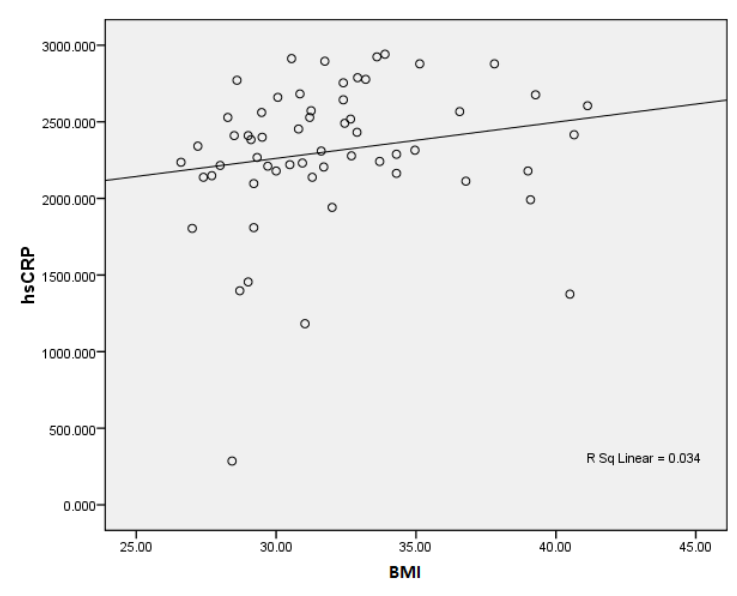

Figure 2. Correlation between hsCRP and BMI.

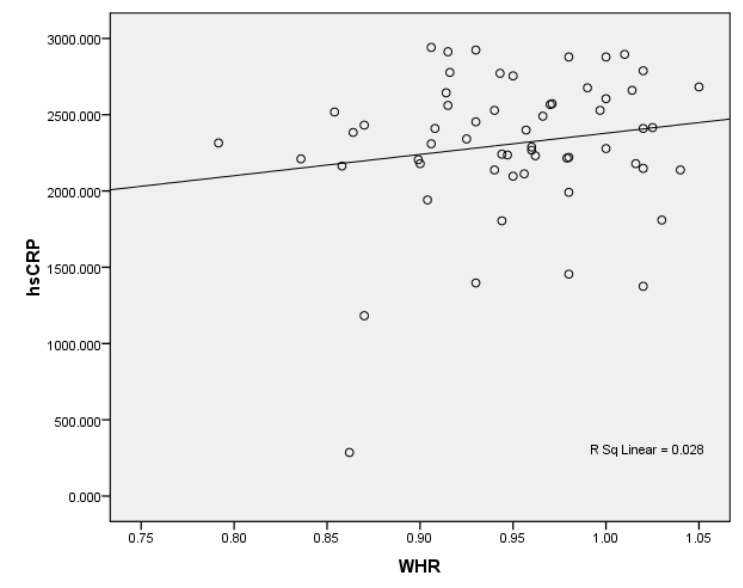

Figure 3. Correlation between hsCRP and WHR.

Waist circumference and WHR have stronger effects on increasing the risk of cardiovascular diseases than BMI (Goh et al., 2014). A study in obese children showed that insulin resistance and triglyceride levels are predicted more accurately by the combination of BMI and WHR or waist circumference (Samouda et al., 2015).

This study has some limitations, include physical activity and diet can influence the inflammatory response, and small sample size. Further study with large sample size and controlling of diet and physical activity are needed to examine the correlation between anthropometric measurements and inflammatory biomarker in obese adolescents in Indonesia.

\section{Conclusions}

Waist circumference could serve as an indicator of inflammatory states in obese adolescents.

\section{References}

Arbel, Y., Birati, E.Y., Shapira, I., Finn, T., Berliner, S., Rogowski, O. (2012). Comparison of different anthropometric measurements and inflammatory biomarkers. International Journal of Inflammation, $\quad 2012, \quad 1-5$. https://doi.org/10.1155/2012/124693

Ayoub, M., Zouaoui, C., Grira, N., Kochkar, R., Stambouli, N., Bouguerra, C., Zidi, B., Ghazouani, E., Mazigh, C., Aouni, Z. (2015). Correlation between dietary intake and inflammatory biomarkers in a Tunisian obese group. Journal of Biosciences and Medicines, $\quad 03$, 108-13. https://doi.org/10.4236/jbm.2015.311014

Bea, J.W., Funk, J., Hetherington-Rauth, M., Wertheim, B.C., Mosquiera, L., Thuraisingam, R., Lee, V., Blew, R., Lohman, T., Roe, D.J., Going, S. (2018). Anthropometry versus imaging for prediction of inflammation among Hispanic girls: Adiposity and inflammation among Hispanic girls. Obesity, 26, 1594-602. https://doi.org/10.1002/oby.22265

Caminiti, C., Armeno, M., Mazza, C.S. (2016). Waist-to-height ratio as a marker of lowgrade inflammation in obese children and adolescents. Journal of Pediatric Endocrinology and Metabolism, 29(5), 54351. https://doi.org/10.1515/jpem-2014-0526

Castro, A.M., Macedo-de la Concha, L.E., Pantoja-Meléndez, C.A. (2017). Low-grade inflammation and its relation to obesity and chronic degenerative diseases. Revista Médica del Hospital General de México, 80, 101-5. https://doi.org/10.1016/j.hgmx.2016.06.011 del Mar Bibiloni, M., Maffeis, C., Llompart, I., Pons, A., Tur, J.A. (2013). Dietary factors associated with subclinical inflammation among girls. European Journal of Clinical 
Nutrition,

67 ,

1264-70.

https://doi.org/10.1038/ejen.2013.196

Ellulu, M.S., Patimah, I., Khaza'ai, H., Rahmat, A., Abed, Y. (2017). Obesity and inflammation: the linking mechanism and the complications. Archives of Medical Science, $\quad 4$, 851-63. https://doi.org/10.5114/aoms.2016.58928

Goh, L.G.H., Dhaliwal, S.S., Welborn, T.A., Lee, A.H., Della, P.R. (2014). Anthropometric measurements of general and central obesity and the prediction of cardiovascular disease risk in women: a cross-sectional study. BMJ Open, 4, e004138. https://doi.org/10.1136/bmjopen2013-004138

Going, S.B., Lohman, T.G., Cussler, E.C., Williams, D.P., Morrison, J.A., Horn, P.S. (2011). Percent body fat and chronic disease risk factors in U.S. children and youth. American Journal of Preventive Medicine, 41 , S77-S86. https://doi.org/10.1016/j.amepre.2011.07.00 6

Guedes, J.M., Mamêde Neto, J.B., Andaki, A.C.R., Pereira, P.F., Oliveira, M.D. de, Dias, R.S., Paula, S.O. de, Natali, A.J., Rogério, A. de P., Mendes, E.L. (2016). Association of inflammation, dyslipidemia, obesity and physical activity status in children. Motriz: Revista de Educação Física, 22, 18-26. https://doi.org/10.1590/S19806574201600020003

Hastuti, J., Kagawa, M., Byrne, N.M., Hills, A.P. (2017). Determination of new anthropometric cut-off values for obesity screening in Indonesian adults. Asia Pacific Journal of Clinical Nutrition, 26, 650-6. https://doi.org/10.6133/apjcn.072016.09

Hetherington-Rauth, M., Bea, J.W., Lee, V.R., Blew, R.M., Funk, J., Lohman, T.G., Going, S.B. (2017). Comparison of direct measures of adiposity with indirect measures for assessing cardiometabolic risk factors in preadolescent girls. Nutrition Journal, 16, 15. https://doi.org/10.1186/s12937-0170236-7
Ishii, S., Karlamangla, A.S., Bote, M., Irwin, M.R., Jacobs, D.R., Cho, H.J., Seeman, T.E. (2012). Correction: Gender, obesity and repeated elevation of C-reactive protein: Data from the CARDIA Cohort. PLoS ONE, 7(4), 36062. https://doi.org/10.1371/annotation/5459a88 b-e488-4d4c-bd59-e7e8e99c8867

Lee, H., Lee, I.S., Choue, R. (2013). Obesity, inflammation and diet. Pediatric Gastroenterology, Hepatology \& Nutrition, 16 , https://doi.org/10.5223/pghn.2013.16.3.143 Marques-Vidal, P., Bochud, M., Bastardot, F., Lüscher, T., Ferrero, F., Gaspoz, J.-M., Paccaud, F., Urwyler, A., von Känel, R., Hock, C., Waeber, G., Preisig, M., Vollenweider, P. (2012). Association between inflammatory and obesity markers in a Swiss population-based sample (CoLaus Study). Obesity Facts, 5, 734-44. https://doi.org/10.1159/000345045

Mendes, E.L., Andaki, A.C.R., Brito, C.J., Guedes, J.M., Santos, M.P.M., Mota, J. (2017). Waist circumference to height ratio predicts inflammatory risk in children. Annals of Human Biology, 44, 303-8. https://doi.org/10.1080/03014460.2016.125 3771

Reyes, M., Gahagan, S., Díaz, E., Blanco, E., Leiva, L., Lera, L., Burrows, R. (2011). Relationship of adiposity and insulin resistance mediated by inflammation in a group of overweight and obese Chilean adolescents. Nutrition Journal, 10, 4. https://doi.org/10.1186/1475-2891-10-4

Roberts, C.K., Hevener, A.L., Barnard, R.J. (2013). Metabolic syndrome and insulin resistance: Underlying causes and modification by exercise training, in: Terjung, R. (Ed.), Comprehensive Physiology, 3(1), 1-58. https://doi.org/10.1002/cphy.c110062

Samouda, H., de Beaufort, C., Stranges, S., Guinhouya, B.C., Gilson, G., Hirsch, M., Jacobs, J., Leite, S., Vaillant, M., Dadoun, F. (2015). Adding anthropometric measures of regional adiposity to BMI improves 
prediction of cardiometabolic, inflammatory and adipokines profiles in youths: a crosssectional study. BMC Pediatrics, 15, 168. https://doi.org/10.1186/s12887-015-0486-5

Schlecht, I., Fischer, B., Behrens, G., Leitzmann, M.F. (2016). Relations of visceral and abdominal subcutaneous adipose tissue, body mass index, and waist circumference to serum concentrations of parameters of chronic inflammation. Obesity Facts, 9 , $144-57$. https://doi.org/10.1159/000443691

Shafiee, G., Qorbani, M., Heshmat, R., Djalalinia, S., Motlagh, M.E., Arefirad, T., Mahdavi Gorabi, A., Najafi, F., Asayesh, H., Kelishadi, R. (2018). Wrist circumference as a novel predictor of obesity in children and adolescents: the CASPIAN-IV study. Journal of Pediatric Endocrinology and Metabolism, 31 , $717-25$. https://doi.org/10.1515/jpem-2017-0206

Sinaga, M., Worku, M., Yemane, T., Tegene, E., Wakayo, T., Girma, T., Lindstrom, D., Belachew, T. (2018). Optimal cut-off for obesity and markers of metabolic syndrome for Ethiopian adults. Nutrition Journal ,17, 109. https://doi.org/10.1186/s12937-0180416-0

Singer, K., Eng, D.S., Lumeng, C.N., Gebremariam, A., M. Lee, J. (2014). The relationship between body fat mass percentiles and inflammation in children: Relationship between body fat mass percentiles and inflammation in children. Obesity, 22, 1332-6. https://doi.org/10.1002/oby.20710

Staiano, A.E., Katzmarzyk, P.T. (2012). Ethnic and sex differences in body fat and visceral and subcutaneous adiposity in children and adolescents. International Journal of Obesity, $\quad 36, \quad 1261-9$. https://doi.org/10.1038/ijo.2012.95

Todendi, P.F., Possuelo, L.G., Klinger, E.I., Reuter, C.P., Burgos, M.S., Moura, D.J., Fiegenbaum, M., Valim, A.R. de M. (2016). Low-grade inflammation markers in children and adolescents: Influence of anthropometric characteristics and CRP and
IL6 polymorphisms. Cytokine, 88, 177-83. https://doi.org/10.1016/j.cyto.2016.09.007

Toemen, L., Gishti, O., Vogelezang, S., Gaillard, R., Hofman, A., Franco, O.H., Felix, J.F., Jaddoe, V.W.V. (2015). Crosssectional population associations between detailed adiposity measures and $\mathrm{C}$-reactive protein levels at age 6 years: the Generation R Study. International Journal of Obesity, 39 , $1101-8$.

https://doi.org/10.1038/ijo.2015.73

Weber, D.R., Levitt Katz, L.E., Zemel, B.S., Gallagher, P.R., Murphy, K.M., Dumser, S.M., Lipman, T.H. (2014). Anthropometric measures of abdominal adiposity for the identification of cardiometabolic risk factors in adolescents. Diabetes Research and Clinical Practice, 103, e14-7. https://doi.org/10.1016/j.diabres.2013.12.05 0

Wolfgram, P.M., Connor, E.L., Rehm, J.L., Eickhoff, J.C., Zha, W., Reeder, S.B., Allen, D.B. (2015). In non-obese girls, waist circumference as a predictor of insulin resistance is comparable to MRI fat measures and superior to BMI. Hormone Research in Paediatrics, 84, 258-65. https://doi.org/10.1159/000439130

\section{Acknowledgments}

The author would like to thanks to Universitas Airlangga, Surabaya, Indonesia for the financial support. 